DE DE GRUYTER OPEN
Journal of Intercultural Management

Vol. 6, No. 1, January 2014, pp. 81-109

DOI 10.2478/joim-2014-0006

Mariusz Bednarek

University of Social Sciences

Aleksander Buczacki

Warsaw University of Technology

Juan Carlos Neri Guzmán M.Sc.

Polytechnic University of San Luis Potosi, Mexico

\title{
Evaluation of performance of local economic activity under an industrial cluster approach
}

\begin{abstract}
The purpose of this article is to make a diagnosis of an economic activity identified as relevant in a local economy, in order to verify if it meets the criteria that characterize an industrial cluster.

This paper presents the overall results of research which analyzes the case of the candy and chocolate industries from the point of view of industrial clusters. The research is relevant considering that it presents a methodology for measuring the degree of functionality of a productive activity considered as relevant in a local economy under international operation standards, which is not common in studies of countries in Latin America.

The study seeks to answer the following research questions:

- What is an industrial cluster and what are its characteristics ?

- How to identify and evaluate an economic activity under a focus for industrial cluster?

- What are the competitive strengths and opportunities for local economic activity?

- Is it possible to design a strategy to promote the competitiveness of local economic activity?

The paper consists of the following parts:

- An introduction that presents the general problem context of the research subject is

- Theoretical studies and related research methodology
\end{abstract}


- Results of the investigation

- Proposition of strategic intervention to improve the functionality of the local cluster studied

The case study focuses on San Luis Potosí State, México, and it seeks to demonstrate the need to carry out industrial cluster initiatives as a strategy to promote enterprise development and strengthen economic activities in the manufacture of candies and chocolate, identified as relevant in the local context.

Keywords: Industrial policy, processes and incentives, government policy, institutions and growth, model construction and estimation.

\section{Introduction}

Competing in a globalized world requires increased competitiveness for individuals, firms, regions, industries and countries. In the 1980's, Mexico began a policy of economic liberalization that has resulted in the signing of 11 trade agreements involving 43 countries. This has led to a rise in export of about 12\% annually between 1987 and 2010. Unfortunately, increased of export is not accompanied by increased competitiveness.

Usually the problems of competitiveness are due to the production infrastructure of the companies, the industrial cluster approach shows that there are also striking problems in the context of trade liberalization. Trade liberalization is evidenced as a company's ability to adapt to cooperative work and a corporate culture to adopt an attitude of customer service. Other evidence includes the process to determine the characteristics of the goods or services required, to implement continuous improvement actions, and to make use of innovation practices.

The research objective is to demonstrate the need to carry out industrial cluster initiatives as a strategy to promote enterprise development and strengthen economic activities identified as relevant in the local context. It seeks to define a strategic agenda that includes multi-institutional actions to improve the competitiveness of enterprises and indirectly to seek improvements in the living standards of citizens.

The basic idea is to assist in strengthening local industries to become the anchor of development transforming them into efficient and competitive economic units, generating their own benefits by participating in the international market. In this case has been selected sector of candies and chocolates.

The aim of this study is to propose an alternative way to study economic activities in order to identify areas of opportunity that will allow these activities to operate in a more efficient and competitive manner through the industrial cluster approach. The study seeks to contribute to the methodological tools that facilitate the design and identification of policies for development, 
competitiveness and innovation. The scope of research includes the economic activities with a high potential for development along with a strong component of local origin, i.e. relevant manufacturers with a background in the region, the specific case is the candy and chocolate industry in San Luis Potosí State, Mexico.

\section{Theoretical framework}

Industrial clusters have been identified as a successful strategy to promoting the competitiveness of companies and consolidating them in the international market. The theory is not new and dates back to the 90's as an initiative for companies to survive in the international crisis. Some of the most important theoretical proposals are:

The model of the Diamond by Michael E. Porter

Porter's diamond model provides insight into the role of a cluster in the context of competitiveness for companies. A cluster is defined as follows:

"Clusters are geographic concentrations of interconnected companies, specialized suppliers, service providers, firms in related industries, and associated institutions (for example, universities, standards agencies, and trade associations) in particular fields that compete but also cooperate. Critical masses of unusual competitive success in particular business areas, clusters are a striking feature of virtually every national, regional, state and even metropolitan economy, especially those of more economically advanced nations" [Porter, 2008].

The cluster is represented by the Diamond, the interaction of its four components, which favors competition in an environment of rivalry between the companies in three specific ways:

- Increase of productivity of enterprises and industries;

- Increase of the innovative capacity of enterprises and therefore increasing their productivity, and

- Stimulating the new business formation that supports innovation and that expands the cluster.

The cluster favors the consolidation of a business environment in which companies, especially local ones, use innovation as the natural mechanism of survival in the medium and long term.

In this way a cluster (see Figure 1) is converted into a space for communication between companies acting together, which favors the generation of positive externalities, promotes exports, foreign direct investment, the creation of new businesses, fostering productivity and innovation, contributing to the emergence of competitive advantages; of course this is not achieved by itself, but requires implementing cluster initiatives. 
Figure 1. Sources of Locational Competitive Advantage.

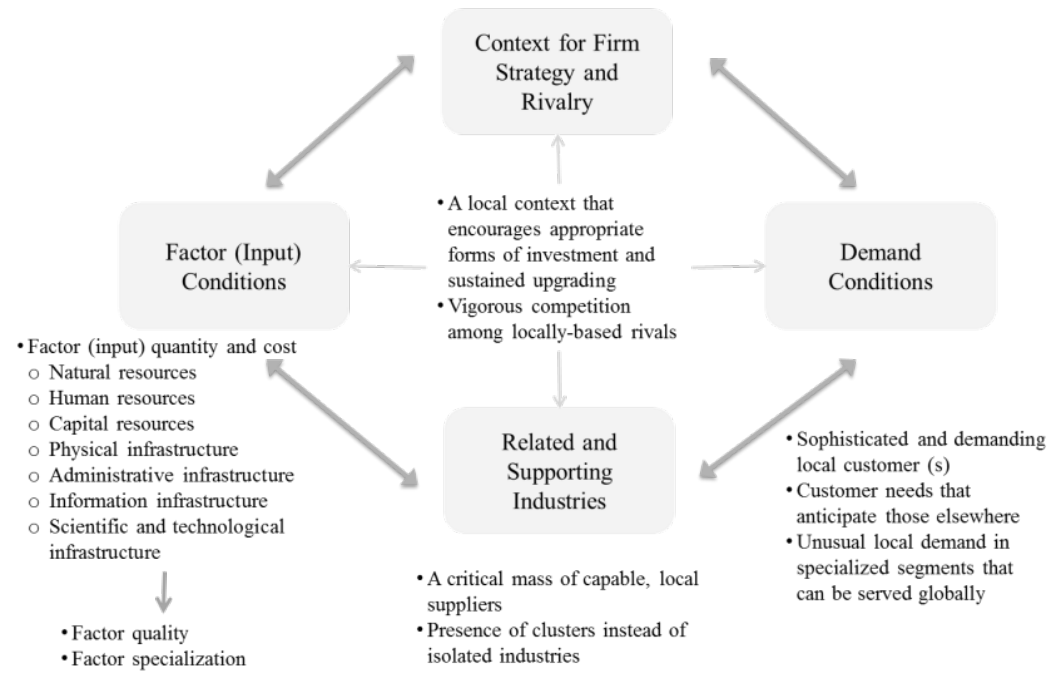

Source: [Porter M., 2008].

A cluster affects competitiveness and innovation through the different components of Porter's diamond:

1. In the condition of the factors, physical infrastructure promotes productivity of companies through the quality of the road network and public services, meanwhile with the involvement and cooperation of higher education institutions and business organizations contribute to improve efficiency, quality and specialization of certain areas of the cluster. Also located here is the administrative infrastructure that determines the information available, updating and system flexibility legal or tariff regulation can benefit all participants and improve the business environment;

2. In the context of company: strategy and rivalry, which consider the rules and incentives that govern the type and intensity of local rivalry, promote investment, stimulate the job market, encourage and regulate intellectual property, foreign trade, foreign investment and sustained improvement. The degree of rivalry is a function of the level of productivity of enterprises, so that the role of the cluster is to promote the transition of enterprises to achieve lower total costs, innovate, increase investment levels, including intangibles such as training and technology;

3. Regarding the component supporting industries it recognizes that it is a 
function of the cluster to ensure the development of local suppliers to be competitive and promote an environment of rivalry, also seeks to promote the attraction of companies required in the industry and to become part of the advantage offered by the location and concentration of businesses;

4. Finally, the component of demand conditions has a central role in assisting in the transition to the production of goods of high quality, with a strong level of differentiation, development of local markets, identifying and serving future demands, entering the new emerging market segment, attention from foreign markets, etc.

In this sense in an industrial clustering firms can improve their situation, time and effort to shorten the time needed to access new components, services, machinery and other items necessary to implement innovations, whether through new lines of products, new processes or new logistics models and benefit from externalities such as the provision of skilled labor, specialized services, access to marketing networks, etc.

Funnel model

A general representation about the structure of an industrial cluster and its interface with the context and the actors involved is represented in the funnel model. The funnel model takes into account four aspects of the operation of an industrial cluster: 1) It defines a group of companies in a specific economic activity, 2) It takes into account the actors related to their activities as sources of support, 3) It makes a strategic account of the response to market demands and supplies and, 4) It requires decisions to be made based on corporate culture and the country's macroeconomic situation. This model recognizes that there is one more component: CI (Cluster Initiatives). CI is the policy direction that seeks to stimulate activity at three possible levels: regional, attracting industries and promotion of innovation, and science and research activity. The model also takes into account the dynamics of the relationship leading to the generation of a new cluster and the consolidation of the more developed export sectors that promote and disseminate the competitiveness and innovation to the rest of the companies. This enables the cluster to consolidate three dynamics: a) the cluster itself, b) the attraction of additional companies and c) the inclusion and extent of new markets (see Figure 2). 
Figure 2. The business environment and forces of change - the funnel model

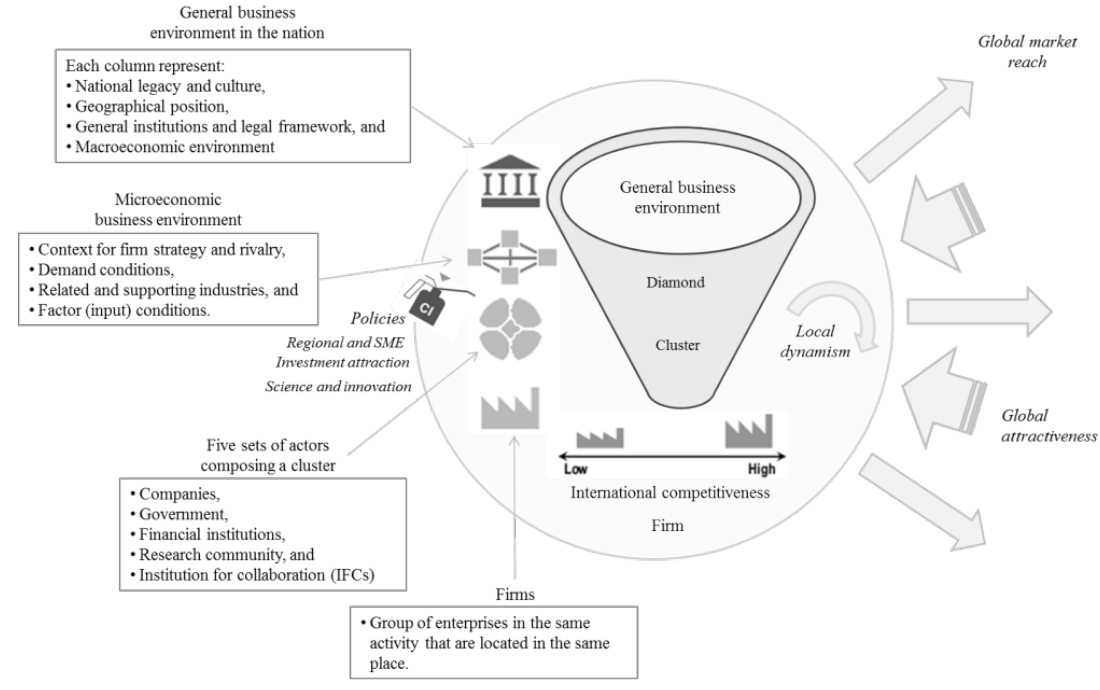

Source: [Sölvell Ö, Lindqvist G, Ketels C., 2003]

The Rabellotti proposal

Rabellotti recognizes that an industrial cluster has special features such as geographic concentration and the presence of at least one leader enterprise, but emphasizes that a strategy to compete in an international context requires close collaboration between suppliers, producers, customers, government, universities and technology transfer centers, as well as financial institutions. This collaborative work allows it to more surely attain modernization, quality and external markets, however it should also develop a culture of cooperation, competition and innovation that allows it to function in the long term and be attentive to the needs of demand and markets. (See table 1).

Table 1. Characteristics of a cluster model

\begin{tabular}{|l|l|l|l|}
\hline \multicolumn{2}{|l|}{ Characteristics of an industrial cluster } \\
\hline $\begin{array}{l}\text { SMEs grouped geo- } \\
\text { graphically, which } \\
\text { are specialized by } \\
\text { industry. }\end{array}$ & $\begin{array}{l}\text { Links with suppliers } \\
\text { and customers based } \\
\text { on information, mar- } \\
\text { ket, exchange of goods } \\
\text { and demand. }\end{array}$ & $\begin{array}{l}\text { Common social and } \\
\text { cultural context that } \\
\text { links economic agents } \\
\text { and creates a culture } \\
\text { code, sometimes } \\
\text { explicit and others } \\
\text { implicit. }\end{array}$ & $\begin{array}{l}\text { Network of public } \\
\text { and private institu- } \\
\text { tions to support } \\
\text { economic agents } \\
\text { operating within the } \\
\text { cluster. }\end{array}$ \\
\hline
\end{tabular}

Source: [Rabellotti R., 1995]. 
Some other authors on innovation and industrial clusters are listed in Table 2 .

Table 2. Conceptual contributions to industrial clusters and innovation systems (approaches, theories and authors)

\begin{tabular}{|l|l|}
\hline Focus & Theory / authors \\
\hline $\begin{array}{l}\text { Industrial } \\
\text { cluster }\end{array}$ & $\begin{array}{l}\text { Porter, Andersson, Schwaag-Serger, Sörvik, Hansson, Benneworth, Dahl, } \\
\text { Ketels, Lindqvist, Möhring, Sölvell, Van der Linde, Rabellotti, Nadvi, Rosen- } \\
\text { feld, Enright. }\end{array}$ \\
\hline Innovation & $\begin{array}{l}\text { Innovation Systems: Winter, Dosi, Paritt, Soete, Andersen, Kuhlman, } \\
\text { Hämäläinen, Niosi, OECD, Marklund, Nelson, Rosenberg, Lundvall, Edquist, } \\
\text { Freeman, Etzkowitz, Metcalfe; Cooke, Braczik, Landabaso, Gulgrandsen, } \\
\text { Gebhardt, De Castro, Silva; Schumpeter, Arrow, Breschi, Malerba, Orsenigo; } \\
\text { Carlson \& Jacobsson, Metcalf, Williamon, Amable, Petit, Boyer. }\end{array}$ \\
\cline { 2 - 2 } & $\begin{array}{l}\text { Knowledge economies and learning regions: Mansell, Machlup, Florida, An- } \\
\text { tonelli, Ferráo. }\end{array}$ \\
\cline { 2 - 3 } & $\begin{array}{l}\text { Forms and innovation networks: Aydalot, Maillat, Camagni, Storper, Cre- } \\
\text { voisier. }\end{array}$ \\
\cline { 2 - 3 } & $\begin{array}{l}\text { Local and regional development: Stöhr, Quévit, Max-Neef, Friedman, Boisier, } \\
\text { Méndez, Vázquez Barquero. }\end{array}$ \\
\cline { 2 - 3 } & $\begin{array}{l}\text { Economic theory of innovation and innovation cycles: Freeman, Soete, } \\
\text { Schumpeter, Dosi, Pavitt, Rosenberg, Pérez. }\end{array}$ \\
\hline
\end{tabular}

Source: Authors' elaboration based on Dahl (2001) and others.

A clearer way to visualize the strategy and the components of an industrial cluster is shown in Figure 3, in which highlight factors determining of the innovation and competitiveness are presented. These factors enable a group of companies to move towards the stage of international competition, but it needs to consider issues such as strengthening the supply chain and marketing, carrying out strategic alliances, establishing business collaboration networks, taking into account mainly market trends (national and international), expectations of demand and the macroeconomic context. In this diagram, as can be observed, innovation plays a key role in the consolidation of industrial clusters to participate in a competitive market. 
Figure 3. Innovation and factors that promote competitiveness

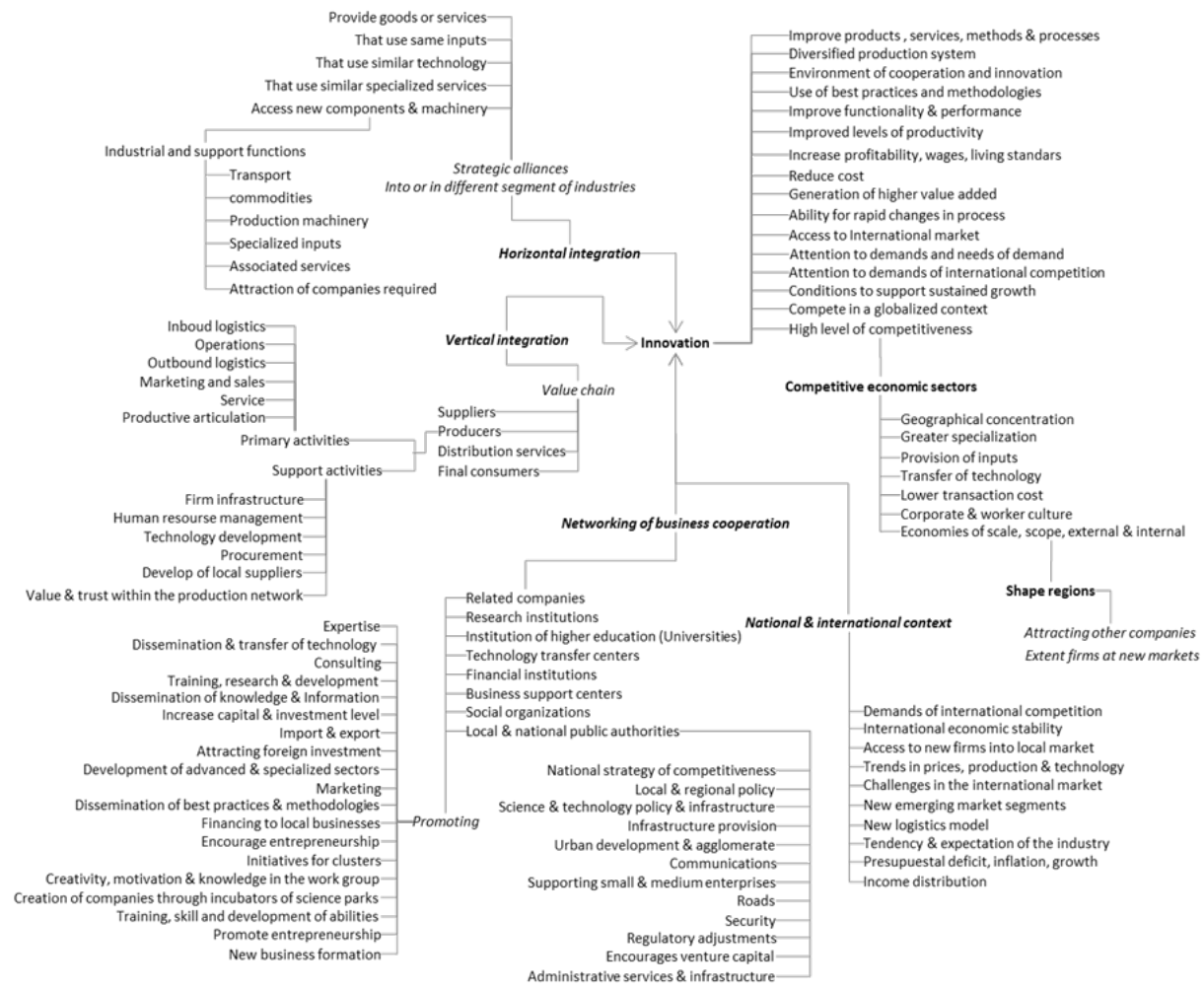

Source: Own development

Key Concepts to define a cluster

The same way, doing a count of the leading cluster theorists, it is possible to identify keywords that summarize the characteristics of a cluster. Figure 4 represents through a relational diagram the main components that give shape to the idea of cluster, each node has identified the key definitions that restrict their scope and field of study. These major components are the foundation of the design of our model for measuring the functionality of a cluster, while the keywords represent the variables of the same. 
Figure 4 Concepts defining a cluster's components.

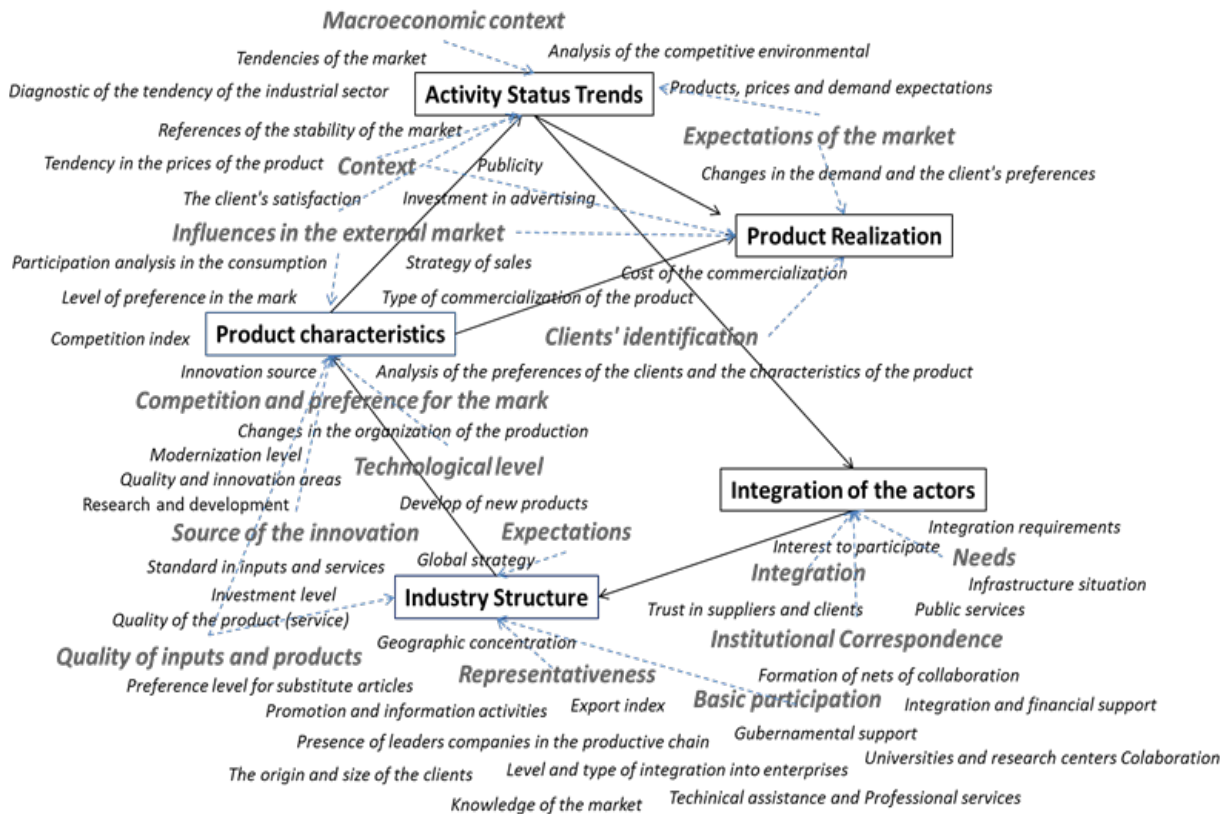

Source: Own development

Methodology to define the model of an industrial cluster

The analysis of industrial clustering is performed using a conceptual model (see Figures 3 and 4), which allows to sort the most important aspects that define a cluster into five major categories. The model thus represents and provides a simple way to measure (quantitatively) the functionality of the cluster, and summarize the result in a general indicator. The major components of the model are:

1) Industry structure;

2) Product realization;

3) Integration of the actors;

4) Product characteristics;

5) Activity status trends.

The analysis of each component will enable the identification of the level of consolidation in the production of chocolate and candy and learning what specific areas of opportunity will facilitate the functional increase of the cluster 
as a whole. This will allow us to make some recommendations to increase the level of functionality, competitiveness and innovation.

The model considers a total of 56 variables, of which 44 are located in the category of soft data that is derived from surveys (79\%), and 12 in the category of hard data gathered from official institutions (21\%). The questionnaire through which information was collected in companies includes three types of variables: nominal, dichotomous and scale which uses numeric values (absolute or percentage) and Likert intervals (3 and 5 ranges). This information is supplemented by statistical information, interviews, field studies, and field work.

The 56 variables are grouped to form 20 indicators which in turn are arranged to define five components that represent the model of industrial clustering functionality. Each variable is calculated in a particular way and made comparable through a statistical process of standardization. The variables are grouped as shown below (Table 3 ):

The model calculates a general index of cluster functionality, which reflects the intensity of consolidation of the different components. The ideal or maximum value is 5 , meaning that each component reflects the ideal operation of the firms under cluster practices, activity that works with standards which may be identified with a successful cluster. A value of zero means that there is no evidence that the companies identified in the chocolate or candy industry operate with some indication of industrial clustering.

The overall result and the individual component results are interpreted through a comparative analysis. This means the model can be applied in two or more industrial activities and the results can be compared to identify best practices in each industry and propose specific actions to overcome the weaknesses identified in each industry.

The first component of the model is a study of the industry structure. It allows for the measurement of the production chain environment and its functionality. 
Table 3 Indicators and components of the Global Index of Industrial Cluster

\begin{tabular}{|c|c|c|}
\hline General Index & Component & Indicator \\
\hline \multirow{20}{*}{$\begin{array}{l}\text { Index of Cluster } \\
\text { Functionality }\end{array}$} & \multirow[t]{5}{*}{ Industry Structure } & Representativeness \\
\hline & & Technological level \\
\hline & & Integration \\
\hline & & Expectations \\
\hline & & Interest \\
\hline & \multirow[t]{3}{*}{ Product Realization } & Clients' identification \\
\hline & & Commercialization indicators \\
\hline & & Expectations of the market \\
\hline & \multirow{3}{*}{$\begin{array}{l}\text { Integration of the } \\
\text { actors }\end{array}$} & Institutional Correspondence Matrix \\
\hline & & Basic participation \\
\hline & & Needs \\
\hline & \multirow{6}{*}{$\begin{array}{l}\text { Product character- } \\
\text { istics }\end{array}$} & Context \\
\hline & & Influences in the external market \\
\hline & & Competition and preference for the mark \\
\hline & & Source of the innovation \\
\hline & & Publicity \\
\hline & & Quality of inputs and products \\
\hline & \multirow{3}{*}{$\begin{array}{l}\text { Activity Status } \\
\text { Trends }\end{array}$} & National-international context of the competition \\
\hline & & Macroeconomic context \\
\hline & & Changes in the demand and the client's preferences \\
\hline
\end{tabular}

Source: Own development 
Table 4 Indicators and variables of the "Industry Structure" component

\begin{tabular}{|c|c|}
\hline Indicator & Related variables* \\
\hline Representativeness & $\begin{array}{l}\text { - Presence of companies in the productive chain } \\
\text { - Representativeness in the productive chain } \\
\text { - Historic reference in the productive chain } \\
\text { - Enterprises origin } \\
\text { - Participation in the economic sector }\end{array}$ \\
\hline Technological level & $\begin{array}{l}\text { - Modernization level } \\
\text { - Investment level } \\
\text { - Technological level } \\
\text { - Machinery and equipment investment } \\
\text { - Changes in the organization of the production } \\
\end{array}$ \\
\hline Integration & $\begin{array}{l}\text { - Knowledge of the supply chain } \\
\text { - Trust in suppliers and clients } \\
\text { - Time of relationship with suppliers and clients } \\
\text { - Standard in inputs and services } \\
\text { - Formation of nets of collaboration } \\
\end{array}$ \\
\hline Expectations & $\begin{array}{l}\text { - Knowledge of the market } \\
\text { - Tendencies of the market } \\
\text { - Products, prices and demand expectations }\end{array}$ \\
\hline Interest & $\begin{array}{l}\text { - Knowledge of the industry. } \\
\text { - Interest to participate. }\end{array}$ \\
\hline
\end{tabular}

*Some variables were obtained from more sophisticated calculations, for example the representativeness in the production chain was obtained by applying the index of local specialization.

Source: Own development

The second component, "Product Realization," allows the analysis of the value chain including market development, distribution and sale of the product.

Table 5 Indicators and variables of the component "Product Realization"

\begin{tabular}{|l|l|}
\hline Indicator & Related variables \\
\hline Clients' identification & - The origin and size of the clients \\
\hline Commercialization indicators & - Type of commercialization of the product \\
& - Cost of the commercialization \\
& - Strategy of sales \\
- Participation into investment \\
\hline Expectations of the market & - References of the stability of the market \\
& - Expectations of the stability of the market \\
\hline
\end{tabular}

Source: Own development

The third component, "Integration of the actors," measures the level of communication and participation between enterprises and support institutions (actors). 
Table 6 Indicators and variables of the component "Integration of the actors"

\begin{tabular}{|c|c|}
\hline Indicator & Related variables \\
\hline $\begin{array}{l}\text { Institutional Correspon- } \\
\text { dence Matrix }\end{array}$ & $\begin{array}{l}\text { - Level and type of integration into enterprises } \\
\text { - Integration and financial support } \\
\text { - Governmental support } \\
\text { - Technical assistance and Professional services } \\
\text { - Universities and research centers Collaboration } \\
\text { - Formation of nets of collaboration }\end{array}$ \\
\hline Basic participation & $\begin{array}{l}\text { - Promotion and information activities } \\
\text { - Participation into related events }\end{array}$ \\
\hline Needs & - Integration requirements \\
\hline
\end{tabular}

Source: Own development

The fourth component identifies the characteristics of the product and its influence the local market competition.

Table 7 Indicators and variables of the component "Product characteristics"

\begin{tabular}{|l|l|}
\hline Indicator & Related variables \\
\hline Context & - Tendency in the prices of the product \\
\hline $\begin{array}{l}\text { Influences in the external } \\
\text { market }\end{array}$ & $\begin{array}{l}\text { - Export index } \\
\text { - Participation in the destination of the production }\end{array}$ \\
\hline $\begin{array}{l}\text { Competition and brand } \\
\text { preference }\end{array}$ & $\begin{array}{l}\text { - Level of preference in the mark } \\
\text { - Preference level for article substitute }\end{array}$ \\
\hline Source of the innovation & $\begin{array}{l}\text { - Innovation source } \\
\text { - Origin of the innovation } \\
\text { - Development of new products }\end{array}$ \\
\hline Publicity & - Percentage of investment in advertising \\
\hline $\begin{array}{l}\text { Quality of inputs and prod- } \\
\text { ucts }\end{array}$ & $\begin{array}{l}\text { - Competition index } \\
\text { - Index of the quality for the link of the chain } \\
\text { - The client's satisfaction } \\
\text { - Practices of the competition }\end{array}$ \\
\hline
\end{tabular}

Source: Own development

Finally, the "Activity status trends" component takes into account the national and international context.

Table 8 Indicators and variables of the component "Activity Status Trends"

\begin{tabular}{|c|c|}
\hline Indicator & Related variables \\
\hline $\begin{array}{l}\text { National-international con- } \\
\text { text of the competition }\end{array}$ & $\begin{array}{l}\text { - Diagnostic of the tendency of the industrial sector and their } \\
\text { expectations. } \\
\text { - Analysis of the competitive arena } \\
\text { - Analysis of the Diamond }\end{array}$ \\
\hline
\end{tabular}




\begin{tabular}{|l|l|}
\hline Macroeconomic context & $\begin{array}{l}\text { - Tendency of the main macroeconomic variables related to } \\
\text { the acting of the sector: } \\
\text { - Scale of payments (foreign debt); Inflation, investment } \\
\text { (capital), growth, income distribution, exports, strengthen } \\
\text { internal capacity of the companies }\end{array}$ \\
\hline $\begin{array}{l}\text { Changes in the demand and } \\
\text { the client's preferences }\end{array}$ & $\begin{array}{l}\text { - Analysis of the preferences of the clients and the character- } \\
\text { istics of the product }\end{array}$ \\
\hline
\end{tabular}

Source: Own development

The model calculates a general Index of Cluster Functionality, which reflects the intensity of consolidation of the different components.

A questionnaire is the basic method of gathering the information supporting indicators and measuring the overall activity of each of the producing companies of the cluster. This information is supplemented by statistical information, interviews, field studies, and field work.

\section{Sample size}

The number of companies studied was 104 out of the 288 that make up the sweet and chocolate industry, the size of the sample is representative and was calculated using the formula of sample size for finite population with a confidence level of $90 \%$, a level of error of $5 \%$, the formula is as follows:

$$
n=\frac{\mathrm{N} Z_{\propto}^{2} \mathrm{Pq}}{E^{2}(N-1)+Z_{\propto}^{2} \mathrm{Pq}}
$$

Where $N=$ population size, $Z=$ value of the normal distribution, $\nabla=$ confidence level chosen, $\mathrm{E}=$ error in the population, $\mathrm{P}=$ proportion of the population

The selection of the companies took into account their role in the productive chain, prioritizing, in order production companies, primary suppliers, secondary suppliers, distributors and traders (see table 9).

Table 9 Companies studied according to industry and their classification in the productive chain

\begin{tabular}{|l|l|l|l|}
\cline { 2 - 4 } \multicolumn{1}{c|}{} & Candy firms & Chocolate firms & Total \\
\hline Producers & $84 \%$ & $100 \%$ & $88 \%$ \\
\hline Primary suppliers & $56 \%$ & $54 \%$ & $55 \%$ \\
\hline Secondary suppliers & $26 \%$ & $38 \%$ & $31 \%$ \\
\hline Trade and distribution & $22 \%$ & $19 \%$ & $21 \%$ \\
\hline Total & 56 & 48 & 104 \\
\hline
\end{tabular}

Source: Own development 


\section{Identification of relevant local economic activities}

The state of San Luis Potosí ranks 16th by total population of the Mexican states. It contains the 10 th largest city. However, it is ranked 27 th in poverty (marginalization) and 21st in level of competitiveness. These statistics would indicate the need for San Luis Potosí to undertake initiatives to promote development to improve the living standards of its population and the competitiveness in industrial activity. In San Luis Potosí the manufacturing industry represents the main economic activity and accounts for $63 \%$ of gross total production. The most important sub-sectors within the manufacturing industry are: basic metal, transport equipment manufacturing, food and electric power equipment, which account for $24.4 \%, 17 \%, 15 \%$ and $12.8 \%$ of gross total production in this sector. San Luis Potosí is one of the 10 (of 32) entities in Mexico where the food industry is highly specialized, so it is a representative entity of this sector.

The chocolate and candy industry represents $33.3 \%$ of the food industry. According to the value of the gross total production, the activity of the candy and chocolate industry in San Luis Potosi, by itself, is more important than activities such as plastic industry, mining, paper industry or transport (see Table 10).

Table 10. Main economic activities according to the contribution to GDP in San Luis Potosí. 2010

\begin{tabular}{|l|l|l|l|l|}
\hline Activity & Gross Production & Employment & Enterprises & Investment \\
\hline Basic metalindustries & $15.97 \%$ & $2.08 \%$ & $0.06 \%$ & $3.63 \%$ \\
\hline Transport equipment & $11.22 \%$ & $5.81 \%$ & $0.11 \%$ & $14.88 \%$ \\
\hline Food industry & $9.75 \%$ & $5.42 \%$ & $3.44 \%$ & $4.33 \%$ \\
\hline Electrical equipment & $8.35 \%$ & $2.57 \%$ & $0.03 \%$ & $7.50 \%$ \\
\hline Retail & $5.49 \%$ & $25.86 \%$ & $46.45 \%$ & $8.12 \%$ \\
\hline Non metallic minerals & $5.48 \%$ & $1.49 \%$ & $0.71 \%$ & $6.93 \%$ \\
\hline Electricity, gas \& water & $5.11 \%$ & $1.19 \%$ & $0.09 \%$ & $12.87 \%$ \\
\hline Construction & $3.96 \%$ & $4.38 \%$ & $0.66 \%$ & $3.36 \%$ \\
\hline wholesale sales & $3.74 \%$ & $5.45 \%$ & $3.18 \%$ & $5.33 \%$ \\
\hline $\begin{array}{l}\text { Sugar, candies and chocolate } \\
\text { manufacturing }\end{array}$ & $3.25 \%$ & $1.38 \%$ & $0.09 \%$ & $1.58 \%$ \\
\hline Plastic & $2.77 \%$ & $1.37 \%$ & $0.07 \%$ & $1.85 \%$ \\
\hline Minning & $2.51 \%$ & $0.91 \%$ & $0.16 \%$ & $4.68 \%$ \\
\hline Paper & $2.50 \%$ & $0.98 \%$ & $0.08 \%$ & $2.33 \%$ \\
\hline Transportation & $2.31 \%$ & $2.72 \%$ & $0.48 \%$ & $4.56 \%$ \\
\hline Media services & $2.30 \%$ & $0.98 \%$ & $0.30 \%$ & $4.73 \%$ \\
\hline Chemical & $2.25 \%$ & $0.43 \%$ & $0.12 \%$ & $0.08 \%$ \\
\hline
\end{tabular}




\begin{tabular}{|l|l|l|l|l|}
\hline Activity & Gross Production & Employment & Enterprises & Investment \\
\hline Other activities & $22.79 \%$ & $42.39 \%$ & $47.42 \%$ & $17.57 \%$ \\
\hline
\end{tabular}

Source: INEGI. Censos Economicos 2009.

Thus, the food industry in San Luis Potosi (including the manufacture of candy and chocolate) is a representative activity for implementing industrial clustering policy. It is also worth mentioning that in San Luis Potosi, the chocolate industry, dominated mainly by two companies well known in the local market, has a strong tradition in the economy. These companies are the Costanzo chocolate factory, which began operations in 1930 with more than 100 employees, and La Frontera chocolate factory, which started to operate in 1890. The company's success is attributed to the high quality of raw materials and their $100 \%$ natural products. San Luis Potosi also has two large manufacturers of candies, Canel's and Ricolino, both international companies with more than 65 years in Mexico. The industry chain includes a total of 152 related enterprises: 46 as main links of the chain (producers), 43 in support products and activities (suppliers) and 63 in wholesale and retail sale.

\section{Findings of the level of functionality of the industrial clustering}

The index of cluster functionality of both industries is presented in Figure 5 . This is the result of the quality and the preference of their product over the competition in the target market and with the knowledge of how to satisfy customer demands.

In contrast, the component that has more areas of opportunity to improve for both industries is the integration with respect to the actors. That is, there is no proper integration of all actors involved (suppliers, competitors, customers and institutions of collaboration) in each industry respectively.

Figure 5 Performance levels of components of the cluster model of the chocolate and candy industries.

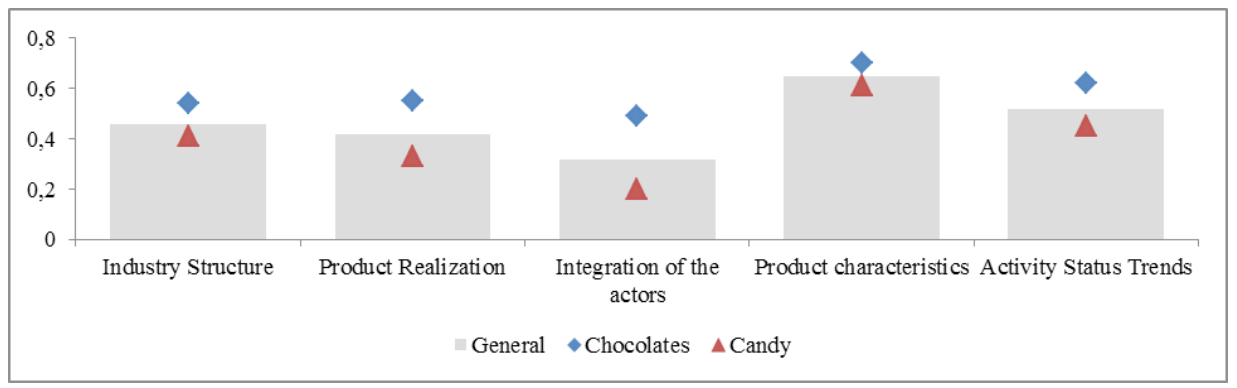

Note: Standardized results from the factor analysis 
To give an idea of the degree of cluster functionality and the level of contribution of each component in the model, the rate of cluster integration as a general equation for both industries will be used.

The equation is:

$\mathrm{CI}=1.639+0.352 \mathrm{IS}+0.065 \mathrm{PR}+0.042 \mathrm{IA}+0.278 \mathrm{PC}+0.336 \mathrm{AST}+0.055$

Where: CI represents the Cluster Integration Index; IS represents the "Industry Structure" component; PR represents the "Product Realization" component; IA represents the "Integration of the Actors" component; PC represents the "Product Characteristics" component, and AST represents "Activity Status Trends" component.

In this model the dependent variable is the rate of integration of the cluster and the independent (or explanatory) variables are the five major components: the Industry Structure, Product Realization, Integration of the Actors, Product Characteristics and Activity Status Trends. The major interpretation of the equation says that to increase the rate of cluster integration (CI), it is necessary to increase, either individually or jointly, the model components. For example, an increase in one unit of Product characteristics (PC) causes the rate of cluster integration to increase 0.278 units if the other components remain constant. Therefore, considering that each component is integrated with different variables, it is necessary to promote the increase of the component through the improvement of the conditions that measure the different variables, which requires carrying out policies and action strategies.

This model (equation) demonstrates that in the chocolate and candy industries in San Luis Potosí, the component that provides the best explanation of functionality with a focus on industrial clusters is the Industry Structure, which is measured by variables such as industry knowledge, trust with suppliers, customers and the level of technology with which firms operate (as previously presented in Table 4).

Figure 6 shows other indicators which identify some socio-economic characteristics in the candy and chocolate industry:

- There are good products and a favorable international environment, but there is no collaborative work and the products are not exported.

- Companies do not know all of the suppliers, producers and customers related to the activity and present in the local economy.

- There is an informal relationship of business between the producers, suppliers and consumers.

- One of the principles of industrial clusters is focus on meeting customer expectations, which is not sufficient in this industry and in this industry is not enough important.

- Companies in the chocolate and candy industries are not used to working collaboratively or joining collaborative networks. 
- There is willingness to cooperate on the part of companies; however a cluster means working together based on cooperation, competition and sharing.

Figure 6 Performance levels of components of the cluster model of chocolate and candy industries.

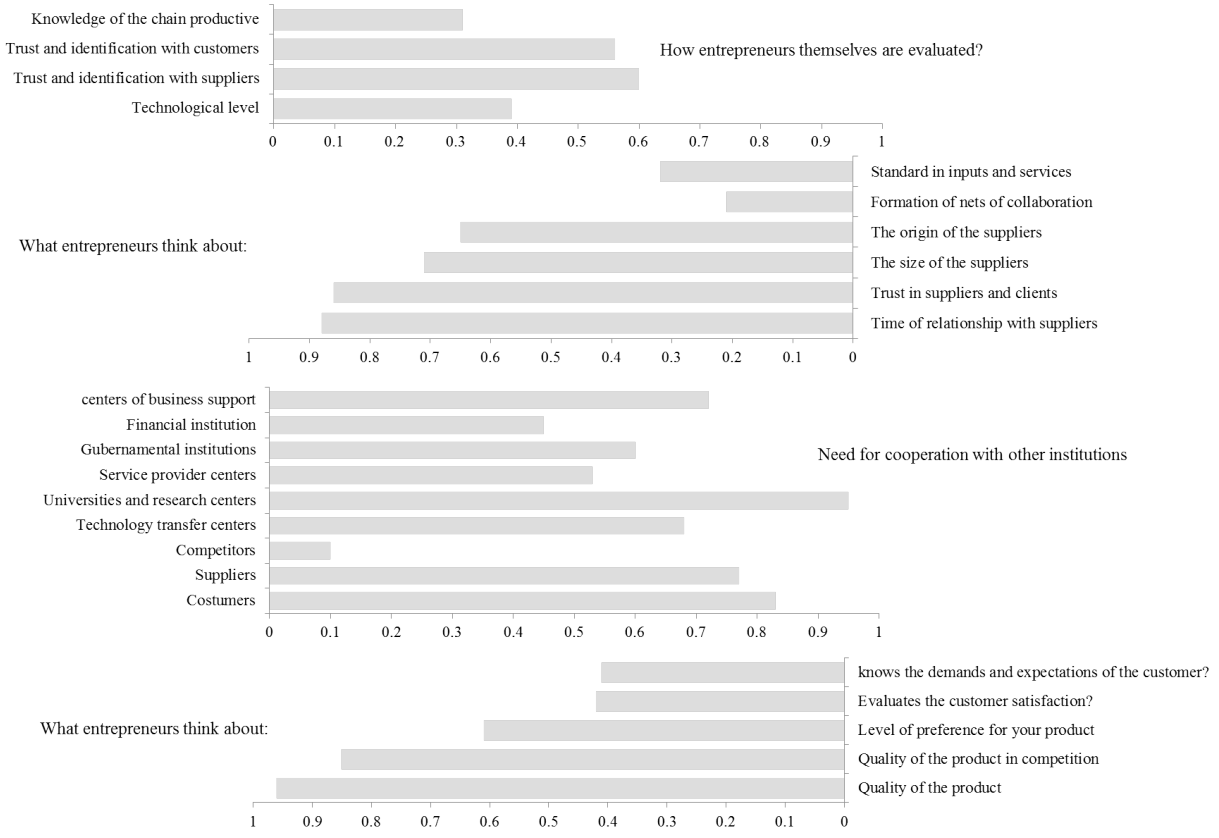

Note: Scores are standardized on a scale of 0 to 1 , where 1 is the better result

Source: Own development

The results show that companies mostly do not operate in a competitive dynamic because:

- The market of production factors is not known by the companies, and there is no efficient supplier-producer-consumer coordination. This is reflected in problems of costs of operation by not having access to the best suppliers / customers and not having the support from the collaborative networks (funding, training, technology transfer, etc.). Due to this the cost of consolidation of a company becomes higher and the process takes longer and is uncertain.

- There is a state of informality and lack of quality standards among participants in the production chain. Due to this products are generated with medium, low and variable quality, it limits the expectations for joining commercialization networks and hence exporting products. 
Moreover, analyzing the needs identified as the most important by the companies, it was found those related to profitability and costs were the most acute, as well as those related with production processes and consolidation of commercial networks. Table 11 shows the most important needs identified by businesses, organized by their type and level of impact.

Table 11. Needs identified by enterprises according to their priority and category

\begin{tabular}{|c|c|c|c|}
\hline Criteria & High & Medium & Low \\
\hline Financial & $\begin{array}{l}\text { The high cost of raw } \\
\text { materials, } \\
\text { High cost of utilities } \\
\text { (public services), } \\
\text { Reducing operating } \\
\text { costs, } \\
\text { Aggressive tax policy }\end{array}$ & $\begin{array}{l}\text { Access to funding pro- } \\
\text { grams, } \\
\text { The low price of the goods } \\
\text { / services produced }\end{array}$ & \\
\hline Capital & & $\begin{array}{l}\text { Need to modernize ma- } \\
\text { chinery and equipment }\end{array}$ & $\begin{array}{l}\text { Access to the latest produc- } \\
\text { tion technology, } \\
\text { Knowledge of technology } \\
\text { transfer centers }\end{array}$ \\
\hline Resources & & $\begin{array}{l}\text { Finding qualified person- } \\
\text { nel }\end{array}$ & Personnel training program \\
\hline $\begin{array}{l}\text { Produc- } \\
\text { tion }\end{array}$ & & $\begin{array}{l}\text { Implement methods to } \\
\text { improve the production } \\
\text { process }\end{array}$ & $\begin{array}{l}\text { Competition from imported } \\
\text { products }\end{array}$ \\
\hline Services & Insecurity & $\begin{array}{l}\text { Participate in government } \\
\text { support programs, }\end{array}$ & $\begin{array}{l}\text { Lack of integration into } \\
\text { enterprise networks, } \\
\text { Advice on legal and admin- } \\
\text { istrative aspects, } \\
\text { Relationship between re- } \\
\text { search centers, } \\
\text { Advice on aspects of operat- } \\
\text { ing standards }\end{array}$ \\
\hline Processes & $\begin{array}{l}\text { Implement Quality } \\
\text { Program }\end{array}$ & & $\begin{array}{l}\text { Implement methods to } \\
\text { improve management }\end{array}$ \\
\hline Commerce & $\begin{array}{l}\text { Business Network } \\
\text { Integration }\end{array}$ & $\begin{array}{l}\text { Identifying foreign mar- } \\
\text { kets }\end{array}$ & \\
\hline
\end{tabular}

Source: Own development

Companies in the candy and chocolate industry also evaluated the availability of services and revealed their reasons for agreeing to participate in an industrial cluster, Table 12 shows the results.

According to the companies' rating of the functionality and quality of services offered in the city, the highest scores were noted in Internet access, telephone service, provision of electricity, water, garbage collection and road conditions 
of the city to the rest of the country. The services identified as deficient have to do with public safety, road conditions within the city, government to business transactions, environmental care and tax policy. It was underlined that the best quality was offered by the utilities (except for the condition of the streets in the city), while the worst-rated area was the authorities' business-friendliness (formalities and taxes).

By other hand, specifically, the companies believe that the most important reasons to participate in an industrial cluster policy would include: the ability to access new markets, strengthening relationships with customers and suppliers, increasing personal contacts and taking advantage of reduced operating costs. These requirements are, indirectly, a consistent response to the needs identified earlier by the companies.

Table 12 Most important reasons to participate in an industrial cluster and evaluation of services for firms that produce chocolate and candy (hierarchical order)

\begin{tabular}{|l|l|}
\hline $\begin{array}{l}\text { Reasons to participate in an industrial clus- } \\
\text { ter }\end{array}$ & Evaluation of services \\
\hline - Access to new markets & - Internet Service Provision \\
\hline - Strengthen relationships with customers \\
and suppliers & , Access to telephone service \\
\hline - Personal contacts & / Electricity provision \\
\hline - Cost advantages & / Provision of drinking water \\
\hline - Introducing new processes / materials & - Cleaning and garbage collection \\
\hline - Quality Assurance & / Roads in the city to the rest of the country \\
\hline - Support for internationalization & - Sewer service functionality \\
\hline - Find partners and support staff & - Cost of electricity \\
\hline - Sharing experiences & - Public Safety \\
\hline - Benchmarking & - Roads and streets in the city \\
\hline - Exchange of experience and new technology & - Governance processes to companies \\
\hline - Cooperation on specific topics & - Environmental Care \\
\hline - Joint use of centralized services & - Tax Policy \\
\hline
\end{tabular}

Source: Own development

\section{Policy to strengthen local clusters}

In general we can summarize the fundamental differences between the characteristics of companies in the candy and chocolate industry and the ideal model of industrial grouping. These relevant differences are shown in Table 13. 
Table 13 Fulfillment of requirements in the industrial cluster analysis in the candy and chocolate industries

\begin{tabular}{|l|l|}
\hline The ideal model of cluster & Situation of the chocolate and candy industry \\
\hline $\begin{array}{l}\text { At least one driver company in the industry } \\
\text { with a presence in the international market } \\
\text { with high influence and local suppliers. }\end{array}$ & $\begin{array}{l}\text { Few companies that export and their influ- } \\
\text { ence is with regional providers (rather than } \\
\text { local). }\end{array}$ \\
\hline $\begin{array}{l}\text { Representative number of companies that } \\
\text { promote economies of scale and compatibil- } \\
\text { ity with the production chain. }\end{array}$ & $\begin{array}{l}\text { Many companies but most operating in the } \\
\text { informal sector as self-subsistence (micro) } \\
\text { activities. }\end{array}$ \\
\hline Collaborative work with support institutions. & $\begin{array}{l}\text { Companies with a low level of involvement } \\
\text { with business associations, institutions of } \\
\text { higher education, research centers and gov- } \\
\text { ernment support. }\end{array}$ \\
\hline $\begin{array}{l}\text { High demand products with quality stan- } \\
\text { dards produced in a continuously innovating } \\
\text { process responsive to changes in demand. }\end{array}$ & $\begin{array}{l}\text { Products of medium quality standards with } \\
\text { low component innovation and no account- } \\
\text { ing of market expectations and demand. }\end{array}$ \\
\hline $\begin{array}{l}\text { Knowledge of the trends in product demand, } \\
\text { pricing and cost of inputs. }\end{array}$ & $\begin{array}{l}\text { Few companies have industry research and } \\
\text { knowledge of market trends. Decisions are } \\
\text { made without regard to diagnosis and useful } \\
\text { information. }\end{array}$ \\
\hline
\end{tabular}

Source: Own development

This means the local industry candy-chocolate industry has leading companies through which to promote policies of industrial clustering, the problem is that the set of companies that perform complementary and input suppliers mostly not operate with efficiency standards and collaborative work is at the initial stage.

According to the characteristics identified in the companies, the proposal to implement initiatives in the candy and chocolate industry cluster focuses on three main strategies. The first lays the groundwork for the organization and includes actions such as promoting partnerships between businesses and the creation of an institution for promoting and coordinating cluster policies. The second strategy has to do with the fundamentals that allow the momentum of activity and includes activities such as creating a fund to promote modernization and innovation in business and standardization of production that can generate higher quality goods. The third strategy allows consolidating these activities through integration of products in commercial networks and exporting markets.

This industrial cluster policy therefore seeks to first ensure an atmosphere of trust and cooperation among firms to move to an improvement in production processes and product quality. The policy also aligns the production for foreign markets in a process with continuous improvement and innovation that allows the product to maintain its position on customer preferences. (see figure 7). 
Figure 7. Stages of consolidation of the industrial cluster model.

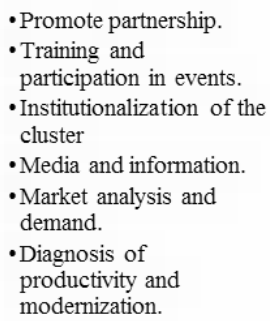

Base
- Participate in

international markets.

- Diversify commercial

- Fund financial support.

- Policy of modernization

of enterprises.

-Innovation strategies.

- Standardization of

production.

-Product Quality networks.

-Product promotion

Consolidate

\section{Source: Own development}

Progress in the consolidation of the chocolate and candy industries takes programmed actions in time and in different aspects. The following tables summarize the identified priority activities that should be carried out in the

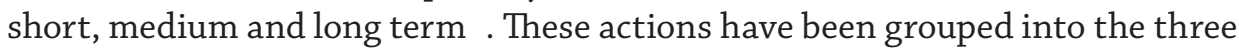
major proposed strategies to reach the competitiveness for the companies studied: innovation, modernization and finance strategies. The modernization strategy is divided into three areas: productive, cultural, and business.

The actions outlined here seek to promote the competitiveness of these activities by strengthening the economic importance in the region, strengthening the production structure, improving product quality and diversifying and expanding the market for their products.

Table 14. Key activities in the innovation strategy according to implementation period

\begin{tabular}{|l|l|}
\hline Period & Innovation strategy \\
\hline Short term & $\begin{array}{l}\text { Conduct a technology assessment in companies according to international } \\
\text { standards and the type of companies. } \\
\text { Develop operating level diagnostics for companies to identify the level of } \\
\text { equipment, innovation, productivity and technological. }\end{array}$ \\
\hline
\end{tabular}




\begin{tabular}{|l|l|}
\hline Period & Innovation strategy \\
term & $\begin{array}{l}\text { Create a fund for financial support for technological upgrading and carry out } \\
\text { innovation activities in companies. } \\
\text { Create and require a degree in best practices, processes and innovation man- } \\
\text { agement for all management and directors. } \\
\text { Agreements with HEI and TTC to carry out systematic innovation activities } \\
\text { and technological development in enterprises. } \\
\text { Implement quality management systems with a focus on customer service and } \\
\text { continuous improvement and an emphasis on innovation. }\end{array}$ \\
\hline Long term & $\begin{array}{l}\text { Companies obtain certification in Quality and Innovation. Companies have } \\
\text { achieved management standards of innovation and technological develop- } \\
\text { ment. } \\
\text { Promote cellular business innovation in companies in the candy and chocolate } \\
\text { industries. }\end{array}$ \\
\hline
\end{tabular}

Source: Own development

Table 15. Key activities in the modernization strategy according to productive environment and implementation period

\begin{tabular}{|l|l|}
\hline Period & Modernization strategy / Productive environment \\
\hline Short term & $\begin{array}{l}\text { Integrate the directory of companies in chocolate and candy industries. } \\
\text { Establishment of a food sector organization in SLP. } \\
\text { Promote business registration in business associations. } \\
\text { Encourage local associations and promote the creation of trusts for the opera- } \\
\text { tion of collective benefit programs. } \\
\text { Design and produce information tools useful for companies in the sector. } \\
\text { Assessment of product quality and competitive analysis. } \\
\text { Conduct a business assessment to meet production requirements for modern- } \\
\text { ization and marketing networks. } \\
\text { Analyze the structure and competitive position of chocolate and candy indus- } \\
\text { tries }\end{array}$ \\
\hline $\begin{array}{l}\text { Medium } \\
\text { term } \\
\text { standards and quality in enterprises. } \\
\text { Implement world-class methodologies and manufacturing techniques to im- } \\
\text { prove production in enterprises. } \\
\text { Implement a development program for customers and suppliers in the choco- } \\
\text { late and candy industries. } \\
\text { Implement techniques to improve management practices in business. }\end{array}$ \\
$\begin{array}{l}\text { Enroll industry companies in national and international quality and innova- } \\
\text { tion programs. } \\
\text { Analyze the creation or promotion of new businesses identifying the struc- } \\
\text { tures necessary in the production of the chocolate and candy industries. }\end{array}$ \\
\hline Long term
\end{tabular}

Source: Own development 
Table 16. Key activities in the modernization strategy according to modernization environment and implementation period

\begin{tabular}{|l|l|}
\hline Period & Modernization strategy / Cultural environment \\
\hline Short term & $\begin{array}{l}\text { Company executive training program with a systemic approach to strength- } \\
\text { ening the relationship between producers, customers and suppliers. } \\
\text { Diploma in clustering with a focus on the food industry aimed at administra- } \\
\text { tive and operational staff in the chocolate and candy industries. } \\
\text { Promote the realization of business events for the exchange of experiences. } \\
\text { Carry out visits to successful companies or regions in the production of candy } \\
\text { or chocolate. } \\
\text { Promote the participation of enterprises in the sector related events (fairs, } \\
\text { conferences, expos, etc.) }\end{array}$ \\
\hline Medium & $\begin{array}{l}\text { Carry out agreements to create a specialty engineer food career specializing } \\
\text { in chocolate and candy industries. } \\
\text { Diploma in production of derivatives resulting from the manufacture of } \\
\text { candy and chocolate. } \\
\text { Technical Assistance Program by IES and business organizations for efficient } \\
\text { use of machinery and the application of techniques of world-class production. } \\
\text { Training program and fiscal support for the promotion and dissemination of } \\
\text { the product. }\end{array}$ \\
\hline Long term & $\begin{array}{l}\text { Rely on chocolate and candy industry staff trained and with experience in } \\
\text { innovation practices. } \\
\text { Create a business environment characterized by cooperation, sharing and } \\
\text { yet competing, which facilitates the practice of innovation and local develop- } \\
\text { ment. }\end{array}$ \\
\hline
\end{tabular}

Source: Own development

Table 17. Key activities in the modernization strategy according to business environment and implementation period

\begin{tabular}{|l|l|}
\hline Period & Modernization strategy / Business environment \\
\hline Short term & $\begin{array}{l}\text { Design and perform studies on the situation of supply and demand in do- } \\
\text { mestic and international food sector, in particular the chocolate and candy } \\
\text { industries. } \\
\text { Development of economic diagnosis of the activity and analysis of consumer } \\
\text { preferences. } \\
\text { Training in business practices. Access to information on market conditions in } \\
\text { the industry. } \\
\text { Evaluate product quality and competition. } \\
\text { Conduct assessments of market trends and future customer demands. } \\
\text { Develop plans to create the image and design the marketing of products de- } \\
\text { rived from the candy and chocolate industries. }\end{array}$ \\
\hline
\end{tabular}




\begin{tabular}{|l|l|}
\hline $\begin{array}{l}\text { Medium } \\
\text { term }\end{array}$ & $\begin{array}{l}\text { Systematic measurement of customer satisfaction. } \\
\text { Promote the competitiveness of the chocolate and candy industries through } \\
\text { export program. } \\
\text { Management and support of tax incentives for export. } \\
\text { Design and implement a comprehensive program to reduce operating costs } \\
\text { and determine competitive pricing. } \\
\text { Strengthen the investment in mass distribution of local chocolate and candy } \\
\text { products. }\end{array}$ \\
\hline Long term & $\begin{array}{l}\text { Conduct trade missions to promote the products internationally. } \\
\text { Involvement of local chocolate and candy products in international trade } \\
\text { networks. } \\
\text { Increase the share of exports in the food sector. }\end{array}$ \\
\hline
\end{tabular}

Source: Own development

Table 18. Key activities in the finance strategy according to implementation period

\begin{tabular}{|l|l|}
\hline Period & Finance strategy \\
\hline Short term & $\begin{array}{l}\text { Identify the various institutional programs and criteria set for accessing } \\
\text { financial support in a timely manner, to cope with the needs of business } \\
\text { modernization. } \\
\text { Negotiate the implementation of preferential tax rates with the tax authori- } \\
\text { ties to modernize the process (start-acceleration) that will allow companies } \\
\text { to be financially self-sufficient. }\end{array}$ \\
\hline Medium term & $\begin{array}{l}\text { Promote the establishment of agreements with banks for preferential loans. } \\
\text { Implement a monitoring program of financial and productive performance of } \\
\text { enterprises that will guarantee their passage to efficiently profitable compa- } \\
\text { nies to overcome the problem of competitiveness and costs. } \\
\text { Manage tax breaks to promote the investment in exporting local chocolate } \\
\text { and candy products. } \\
\text { Strengthen the credit policy to facilitate investment as a leverage mechanism } \\
\text { for technology development, business modernization and production link- } \\
\text { ages. }\end{array}$ \\
\hline Long term & $\begin{array}{l}\text { Consolidate financially self-sustaining businesses capable of competing on } \\
\text { price, cost and profitability in the industry through the modernization, ef- } \\
\text { ficiency and effectiveness in the production, marketing and distribution } \\
\text { processes. }\end{array}$ \\
\hline
\end{tabular}

Source: Own development

It is important to note that compliance with the actions defined for each type of strategy requires the involvement of a new autonomous institution responsible for coordinating, promoting and managing the institutions concerned. This institution must ensure that all companies are in agreement with the compliance activities as defined and scheduled. It must also manage the financial support and partnerships with all stakeholders and related businesses. 
Finally we mention that although it was found that the model components that contribute most in explaining the functionality of the cluster in chocolate and candy industries are the Industry Structure and the Activity Status Trends, it is important to note that the contribution of the component of Integration of the actors, although low, tends to increase ongoing initiatives relating to the intervention of the actors involved in the production structure. The actors play the role of facilitators and accelerators in the transition of the industry towards a model of economic competitiveness characterized by the diffusion of innovation and knowledge.

It should be recognized that the industrial cluster approach means working together based on cooperation and sharing while competing. This working philosophy recognizes that companies are not alone in overcoming their competitive weaknesses. They can come to the support institutions that exist (universities, research institutions, business organizations, government, financial institutions and their suppliers and customers) to bridge the gap that exists in both the candy and chocolate industries in a productive corporate culture. It is significant that $87 \%$ of the companies in the candy and chocolate industries would be willing to participate in an industrial cluster policy. However, only $45 \%$ of them would be willing to collaborate, cooperate and compete with other institutions that make up the production chain and institutions to support their industry.

The chocolate and candy industry does not present efficient functionality according to the theoretical ideal definition of cluster. There is in San Luis Potosi a significant physical, productive and business infrastructure, which serves as a base to carry out initiatives to promote the competitiveness of these companies. In this sense the collaborative approach may be the key for companies to have access to interagency support and improve their productivity, so the corporate culture needs to change, remembering that the industrial cluster approach means working together on the basis of cooperation and competition.

\section{Final conclusions}

Even though neither the chocolate and candy industries can fulfill all the requirements to run efficiently as industrial clusters on a point of view of industrial clusters, this research has identified some opportunities for companies to become involved in such activities. Actions to enhance performance focusing on improving profits, competitiveness, innovation and sustainability in the long term in an environment of international competition are included in the proposal.

One relevant component in a cluster is the Activity Status Trends, which indicate that the national and international market demand for chocolate and candies is positive, which is reflected by the prices set for this product. 
Another important and positive component is the Industry Structure, which indicates that the activities of the companies in the food sector show a high trust relationship between producers, suppliers and customers, despite low levels of technological development and knowledge of the industry in general.

The quantitative results of the "cluster model", designed to measure the functionality of an industrial cluster show that aspects that show less functionality are the Integration of the actors and Product realization, as basic aspects of a cluster focus. These two components reflect weak interaction of producing companies with business, financial, government institutions, higher education and research centers.

Weak interaction limits the ability of companies to accelerate their development considering that these institutions are intended and expected to provide development and consolidation support. On the other hand, it also reflects impact of the products in domestic and international markets and a modest policy of product distribution, which speaks of the local businesses spirit and the fear of expanding into overseas markets.

The problems of the companies in the candy and chocolate industries are reflected mainly on two levels, one in production and the other in capability. The problem of production is reflected in the lack of an organizational culture and administrative capability to implement large-scale production quality standards. Also the production system is disconnected from the expectations and demands of consumers. In terms of capacity it means two things, technological infrastructure and the capacity of the human factor. In the candy and chocolate industries, small businesses dominate and this guides their production to local markets with lower quality products than those required in international markets. In terms of capacity, it means two things, technological infrastructure and the capacity of the human factor. In the candy and chocolate industries, small businesses dominate and guide their production to local markets with lower quality products. So, these companies have problems of cost and profitability due to the strong competition in these products and the presence of international products with better prices, variety and sometimes quality. The problem of the local industry will not be solved only with the incorporation of technology into the production system. Some suggestions are: 1. One way to integrate an agenda that leads to defining an industrial cluster policy in the chocolate and candy industries is to link the programs provided by different institutions to support the demands, needs and weaknesses identified in the companies. The linkage results in specific activities to be implemented according to a defined schedule.

2. A way to improve the "integration of the actors" is to implement short-term program support, assistance, technological development and innovation 
in the related companies by implementing cooperation agreements with universities and research centers, and in the medium term formalize agreements to create a bachelor's degree program in the food engineering career path, specialized in candies and chocolate.

3. Most local industries are micro and small enterprises (99\%, with less than 50 employees) which do not have sufficient operating capacity (physical infrastructure, financial and human) to compete in a globalized international context

4. The study suggests rethinking the philosophy of industrial clusters, which recognizes that companies are not alone in overcoming their weaknesses in competitiveness. They can come to support institutions that exist (universities, research institutions, business organizations, government, financial institutions and their suppliers and customers) to bridge the gap that exists in both the candy and chocolate industries in a productive corporate culture. This strategy ensures that the modernization of the company, is reached in the shortest time and cost possible.

\section{Bibliography}

Andersson, T., Schwaag-Serger, S., Sörvik, J. \& Hansson, E. W. (2004). The Cluster Policies Whitebook. Sweden: International Organisation for Economy and Enterprise Development (IKED).

Benneworth, P., Danson M., Raines P., \& Whittam G. (2003). Confusing Clusters? Making Sense of the Cluster Approach in Theory and Practice. European Planning Studies, 11, (5), 511-520.

Cooke, P., Laurentis, C., Tödtling, F. \& Trippl, M. (2007). Regional Knowledge economies: markets, clusters and innovation. Great Britain: Cheltenham.

Dahl, M., S. (2001). What is the essence of geographic clustering? Paper presented in the DRUID Nelson \& Winter Conference, 12-15 June, in Aalborg, Denmark.

Ecotec Research \& Consulting (2006). A Practical Guide to Cluster Development. A Report to the Department of Trade and Industry and the English RDAs. England: DTI.

Edquist, C. y L. Hommen (2008), Small Country Innovation Systems Globalization, Change and Policy in Asia and Europe, Cheltenham, UK: Edward Elgar.

Enright M.J. (2000). The globalization of competition and the localization of competitive advantage: Policies towards regional clustering. In N. Hood \& S. Young (Eds.), The Globalization of Multinational Enterprise Activity and Economic Development. Basingstoke: MacMillan.

Enright, M.J. \& Ffowcs-Williams, I. (2001). Local partnerships, clusters and SME globalization, in Enhancing SME Competitiveness. Paris: OECD.

Etzkowitz, H. (2007) University-Industry-Government. The Triple Helix Model of Innovation. Business School, Newcastle University. 
Etzkowitz, H., \& Loet, L. (1997). The Dynamics of Innovation: From National Systems and 'Mode 2' to a Triple Helix of University-Industry-Government Relations. Research Policy, 29, 109-123.

Etzkowitz H., (2002). The Triple Helix of University -Industry - Government Implications for Policy and Evaluation. Working paper 2002-11, Stockholm: Science Policy Institute.

Ketels, C. (2003). The development of the cluster concept -present experiences and further developments. Prepared for NRW conference on clusters, Duisburg, Germany, 5 Dec 2003: Harvard Business School.

Lagnevik, M., Sjoholm, I., Lareke, A \& Ostberg, J. (2003). The dynamics of innovation clusters. A study of the Food Industry. Cheltenham, UK: Edward Elgar.

Lindqvist, G. (2009) Disentangling Clusters - Agglomeration and proximity effects. Published doctoral dissertation. Stockholm, EFI.

Möhring, J. (2005). Clusters: definition and methodology in OECD. Business clusters: Promoting enterprise in Central and Eastern Europe. OECD.

OECD. (2005). Business Clusters: Promoting enterprise in central and Eastern Europe. Paris.

Osterhammel, J. \& Petersson, N., P. (2005). Globalization: A Short History. New Jersey: Princeton University Press.

Porter, M. E. (2008). On Competition. A Harvard Business Review Book.

Rabellotti, R. (1995). Is There an 'Industrial District Model'? Footwear Districts in Italy and Mexico Compared. World Development, 23, (1), 29-41.

Romesburg, C. (2007). Cluster analysis for researchers. North Carolina: Lulu Press.

Sölvell, Ö., Lindqvist, G., \& Ketels, C. (2003). The Cluster Initiative Greenbook. Stockholm: Ivory Tower. Retrieved from http//: www.cluster-research.org.

Sölvell, Ö., Ketels, C. (2007). Innovation Clusters in the 10 New Member States of the European Union. Europe Innova. Paper No. 1. Luxembourg: Office for Official Publications of the European Communities.

Sölvell, Ö. (2009). Clusters - Balancing Evolutionary and Constructive Forces. (2nd Ed.). Stockholm: Ivory Tower Publishers. Retrieved from http://www.clusterresearch.org

Van der Linde, C. (2002). The demography of cluster: findings from the cluster metastudy. Institute for Strategy and Competitiveness: Harvard Business School.

Vázquez B. A. 2002. Endogenous development. networking, innovation, institutions and cities. Routledge: Londres. 